\title{
ASSOCIATION BETWEEN MATERNAL BEHAVIOR AND CHILD NUTRITIONAL STATUS DURING THE FIRST 1000 DAYS OF LIFE IN TARAKAN, NORTH KALIMANTAN
}

\author{
Ika Yulianti, Rahmi Padilah \\ Public Health Faculty, Universitas Borneo Tarakan
}

\begin{abstract}
Background: The first 1,000 days of life can be stated as the golden period of growth and development of children. It can prevent problems in adulthood, such as obesity, hypertension, diabetes, heart disease, and other chronic diseases. The maternal role took part as the contributing factor. This study aimed to examine the association of maternal behavior and child nutritional status during the first 1000 days of life.

Subjects and Method: This was a cross-sectional study conducted at Mamburungan Public Health Center, Tarakan, North Kalimantan in May 2019. A total of 63 mothers with toddlers under two-years-old was selected for this study. The dependent variable was the nutritional status of toddlers. The independent variable was maternal behavior during the first 1,00o days of child life. The data were collected by a set of questionnaires. The bivariate analysis was performed by chi- square.

Results: Good maternal behavior during the first 1,00o days of life was associated with the improved nutritional status of toddlers under two-years-old, and it was statistically significant $(\mathrm{OR}=6.31 ; \mathrm{p}<0.001)$.

Conclusion: Good maternal behavior during the first 1,00o days of life is associated with the improved nutritional status of toddlers under two-years-old.
\end{abstract}

Keywords: maternal behavior, first 1,00o days of life, toddlers, nutritional status

\section{Correspondence:}

Ika Yulianti. Faculty of Public Health, Universitas Borneo Tarakan. Jl. Amal Lama No. 1 Tarakan, East Kalimantan, Indonesia. Email: ikatamaevan@gmail.com. Mobile: +628115440036. 